\title{
EAST - ASIAN LEAD FIRMS' IMPACT ON THE ELECTRONICS INDUSTRY OF THE V4 COUNTRIES: SAMSUNG AND ITS COMPETITORS
}

\begin{abstract}
The paper investigates the rapid, FDI-driven expansion of the electronics industry in the V4 countries from the second half of the nineties through their inclusion into the global value chains of East-Asian lead firms with their home base in countries, such as in Korea, Taiwan or Singapore and China. The paper analyses opportunities for upgrading of East-Asian manufacturing subsidiaries and their local suppliers in the V4 region towards higher value-added activities, and the level of the subsidiaries' embeddedness after 30 years of their appearance as well as their impact on trade relations between East - Asia and the V4.
\end{abstract}

KEYWORDS: East-Asian lead firms, V4 countries electronics industry, global value chains, global production networks, Samsung Electronics

\section{INTRODUCTION}

The collapse of the socialist regime with centrally-planned economies at the turn of the 1990s left the V4 countries (Czechia, Hungary, Slovakia and Poland) with the immense need for economic restructuring on the macro-level and immediate tasks of adjustments on the level of the companies. Hungary reached the GDP level of its last pre-transformation year only more than 10 years later, in 2000. The new market opportunities on the other hand motivated transnational corporations (TNCs) from developed countries, backed by their host country governments to establish closer ties with the area. Hungary was the first to turn towards foreign direct investments (FDI) by offering opportunities through privatization and green-field industrial sites with tax incentives to foreign enterprises. Shortly thereafter Czechia and Slovakia joined the competition for FDI followed by Poland as well.

The electronics industry played an important role in the CEE countries from the 1970s, however with signs of declining efficiency, lack of innovation and technological investments in the 1980s. The restructuring of this industrial sector from the 1990s, improving its productivity and gaining access to the world markets 
in the new market-driven economic system took place predominantly through the subsidiaries of foreign TNCs, a part of them venturing out from their East-Asian head-offices to the new economic area. The year of EU-accession of these countries in 2004 marks another important milestone in the integration of the V4 region into the global economy, starting already with the pre-accession trade and economic liberalization steps.

After reviewing the development of the electronics sector in the V4 countries in the years of the economic transition, the research focuses on company strategies, in particular in the TV set and components manufacturing sector. A more elaborate picture is drawn from the 30 years history of Samsung Electronics in the CEE region, as a case study of company strategy and regional development. The cooperation-competition phenomenon between the East-Asian giant players has impacted the development of the sector in the individual V4 countries too.

\section{DEVELOPMENT OF THE ELECTRONICS INDUSTRY AND INWARD FDI IN THE V4 COUNTRIES FROM 1990}

\subsection{The gloomy picture at the beginning of the nineties}

After the end of the bipolar geopolitical era, the V4 countries have become integrated into the global markets and started to adjust towards global consumption patterns and standards. "Trade liberalization was an integral part of economic reforms aimed at introducing market competition in the east through the liberalization of prices, by elimination of subsidies and privatization of state-owned industries". [Nikolaidis, 1997:210]. The countries were hardly protected earlier by Western-type import tariffs and non-tariff barriers, as companies had to obtain administrative licences to import. As soon as the administrative barriers disappeared, they were more vulnerable than their Western trading partners. [Nikolaidis, 1997]. In 1989, electronics was suddenly exposed to imports from Asia and domestic large conglomerates gradually lost their markets. [Radosevic, S. 2002]. 


\subsection{FDI and output growth from the mid-nineties}

While Western-European and North-American players in various segments of electronics were cherry-picking from good deals offered through the privatizations, East Asian firms had their first manufacturing base in Western-Europe already, and sporadically ventured out to the new location with lower labour costs to support their European market expansion. From 1997-2007 in the EU-27 countries overall, the industry sector electrical machinery and optical equipment manufacturing grew at a pace of $4.5 \%$ per year, more than double the average for the total manufacturing industry (2.1\% per year). The growth of the sector was driven by radio, television and communication equipment manufacturing (up on average by $5.4 \%$ per year between 1997 and 2007). Finland, Hungary and Ireland were the most specialised EU member states in this sector, as electrical machinery and optical equipment manufacturing provided between $9 \%$ and $10 \%$ of their non-financial business economic value added in 2006. [Eurostat, Statistics explained, 2012]

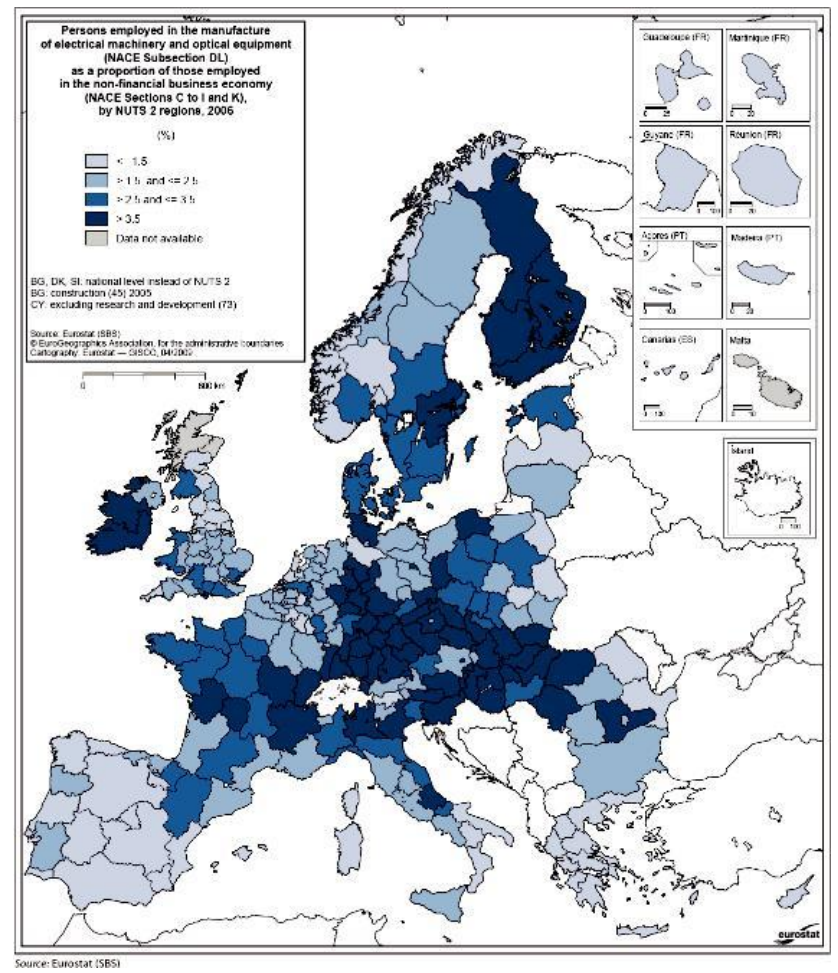

Source: Eurostat Statistics explained 2012

Chart 1. Regional concentration of the Electrical Machinery and Optical Equipment Manufacturing in Europe in 2006 
Chart 1. shows a strong concentration of the industry in Germany, Austria and three of the V4 countries, with highly involved northern regions in Poland as well. In 2007 electronics goods accounted for more than a third of industrial exports from Hungary, and around a quarter of the total from the Czech Republic, Ireland, the Netherlands and Finland. While electronics manufacturing was established on solid ground in the V4 countries during those ten years, $R \& D$ activities have been centred in knowledge clusters outside of the area, encompassing universities, research and design centres and manufacturing facilities, such as Dresden (Germany), Dublin (Ireland), Grenoble (France), Catania (Italy), the Nijmegen-Eindhoven-Leuven axis (Netherlands/Belgium) or around Helsinki (Finland). In the radio, television and communication equipment sector Western OEMs were faced with intense competition from the Far East and tried to encounter with innovation the method of imitation - incremental innovation strategy of East-Asian producers. [Eurostat Statistics explained, 2012].

Exceptionally outstanding was the development in Hungary. "Hungarian growth rate in electronics in 1996-1999 was the highest in the world. With $87 \%$ annual increase they were far ahead of the rates for Chinese and East Asian economies." [Radosevic, 2002: 7]. By 2000 in absolute terms, Hungary and the Czech Republic were "by far the biggest exporters of electronics goods in the region with the overall share of 77\% of CEE exports". [Radosevic, 2004:6], thanks also to investments of East Asian television manufacturing players, like Samsung in Hungary and Matsushita in the Czech Republic.

Processes of accelerated globalization from the beginning of the nineties have led to a new organizational innovation in the development of TNCs, the emergence of their global networks. The ICT revolution allowed the coordination of complex networks at a distance. Decreasing transportation costs through technological advancement and great differences in wage costs between developed and developing/emerging economies made the separation of production stages dispersed geographically crossing borders. These networks have become especially important in the electronics industry and became widespread first in South-East Asia through the expansion of Japanese companies. Shortly thereafter it has been spreading worldwide, resulting in transcontinental trade and investment exchanges, with increasing vertical specialization. These processes influenced the possibilities of the CEE economies in transition in their economic restructuring endeavours.

\section{METHODOLOGICAL FRAMEWORK, LITERATURE REVIEW}

The methodology of the research on the expansion of East-Asian lead firms is connected to two major frameworks of analysis which have been formulated in 
the academic literature after the Millennium, the Global Value Chains (GVCs) and the Global Production Networks (GPNs).

The most widely used framework of analysis in the European academic literature is the Global Value Chains (GVC) research. It finds its roots in Michael Porter's value chain model [Porter, 1985] and the global commodity chain theory, which examines the chains coordinated by buyers and the producers [GereffyKorzeniewiecz 1994, cited by Gereffi, Fernandez-Stark, 2011]. In the case of „producer-driven" commodity chains, it is the beginning (R\&D activity, product development) that gives the strength of the value chain (automotive and electronics sector).

By 2000 the concept was further developed into the framework of global value chains (GVCs) [Gereffi, Lee, 2016]. It concentrates on the sequence of value-added from the conception of the product to the end-user. From a top-down view, it examines how lead firms govern globally their subsidiaries and suppliers. Typical stages of the value chain are $\mathrm{R} \& \mathrm{D}$, product planning and design, production, marketing, distribution and after-sales services. Humphrey and Schmitz (2002) introduced the definition of upgrading, describing it as a movement towards higher value-added activities within the chains. Researchers use their widely accepted typology of upgrading - namely product, process, functional and intersectoral upgrading trajectory of foreign subsidiaries.

At the beginning of the Millenium in many respects, a similar, however distinct analytical framework appeared, i.e. the Global Production Network (GPN). Its analysis in a broader context the cultural, sociological and geographical aspects of the impact that development has on the territories these networks encompass [Henderson, et.al 2002, Parilli et al, 2013]. GPN brings together a "wide array of actors, such as firms, state institutions, labour unions, consumers, non-governmental organizations in the transnational production of economic value" [Coe-Yeung, 2015:15]. Researchers with the GPN framework usually collect information leaning on qualitative methods of case studies and can conclude mainly on the national level.

Fierce competition in the global electronics industry has shifted international firms and host countries' positions in the electronics industry in the past 30 years. Global shifts of dominant players in the V4 countries will be analysed by the research and the GVC, GPN frameworks will be tested on 30 years of activity of Samsung Electronics in the V4 countries. 


\section{COMPANY STRATEGIES: INTERNATIONAL TV MANUFACTURING FIRMS ENTER INTO THE V4 REGION}

\subsection{General overview on corporate-level developments after 1989}

As Radosevic summarizes, "a defining feature of production networks in electronics is their organisation around geographic regions, with each lead firm establishing similar production organisations in Asia, Europe and North America (Linden, 1998; Ernst, 2000)" (Radosevic, 2002:8). At first, Western-European TNCs (Philips, Thomson) in electronics took advantage of the much lower production costs and abundantly available skilled labour in the CEE countries to expand their regional core networks. They dominated the market, based on cathode ray tube technology. Philips built an extensive network for consumer electronics establishing 17 subsidiaries in Hungary from the beginning of the nineties. From among the EastAsian manufacturers, Samsung Electronics from Korea entered first in 1989 into Hungary. US firms joined shortly thereafter as well in other segments of the electronics sector. (IBM Hungary, Motorola Czechia). By the end of the 1990s, the geographic shift of the industry induced Japanese firms (Matshushita, Sony) to relocate their facilities from the EU, in particular from the UK into the region. Global competition reduced the product-life cycle in the electronics industry. Several leading, original innovator TNCs started to concentrate from the midnineties on $R \& D$, brand management and have started from the mid-nineties to outsource partly or wholly their productions to contract manufacturers, or with the widely used term EMS (electronic manufacturing services) partners. They started to design, manufacture, test, distribute and provide return/repair services for Original Equipment Manufacturers (OEMs). After the Millenium several US-based contract manufacturers have expanded their European operations to Czechia, Hungary and Romania (e.g. Flextronics, Celestica, Jabil, Solectron, Sanmina) East-Asian firms started to join Global Production Networks as simple component manufacturers and developed their production and design capabilities - becoming large EMS corporations themselves [Yeung, 2016] e.g. (Foxconn, Taiwan,). Only two important endogenous manufacturers survived the transition period from the CEE region and could follow the path of fast catching up opened by this radical organizational change, the Hungarian Videoton and Czech Tesla Ecimex. [Radosevic, 2002]. Videoton has become from an OEM of various final products the biggest indigenous EMS company with head office in Central Europe. Following the 2008 crisis, the company tripled its turnover by 2018 and ranks no. 3 based on value-added among the European headquartered EMS providers employing more than 10.000 persons. [Videoton website]. The other large Hungarian TV producer under the socialist regime, Orion's main factory in Budapest, was privatized to domestic owners and acquired in 1998 by the Singaporean Thakral group. The many-sided activities of 
today medium-size firm still include LCD TVs. [Thakral website]. Orion's countryside plant was acquired by Samsung Electronics as early as 1989, which have become a major player in the V4 electronics industry even to date. "Strong complementarities between strategies of MNCs, local large and SMEs, state administrative capacity and FDI incentives, jointly with actions of local governments and attraction of EU demand and EU accession have to be taken into account if we are to understand why CEE countries have managed to integrate into global production networks in electronics. The network alignment is driven by MNCs, is pulled by EU demand and confined to local subsidiaries of MNCs." [Radosevic, 2004:12-13].

\subsection{SAMSUNG ELECTRONICS IN THE V4 REGION}

Samsung Electronics' activity in the V4 countries is reviewed in current research both from the aspect of upgrading based on the GVC framework, and the introduction of the array of actors and their role in embeddedness according to the GPN framework. The circumstances for the qualitative research, semi-structured interviews could be created around Samsung Electronics' largest European TV manufacturing facility in Hungary, in the small city of Jászfényszaru. Three interview rounds were achieved with the company in 2015 and 2017 and two interviews with major Hungarian suppliers in 2017, as well as three interviews regarding the local environment: with the mayor of the locating city and the managing director of the Industrial Park, where the factory is based and the head of the related secondary school.

The core research questions put forward with the Samsung case study are the following:

- Have subsidiaries and domestic suppliers within the Samsung Electronics Global Value Chain achieved an upgrading trajectory in the V4 region during the last three decades?

- Have the local subsidiaries been integrated with useful linkages into the host economy?

The evidence from the few empirical research studies is mixed, pointing out that plugging into GVCs in emerging countries does "not necessarily lead to the formation of strong linkages between foreign subsidiaries and domestic firms." [Pavlinek, Zizalova, 2014:5]. Sass-Szalavetz (2012) show that even though the host country may connect in the production stage, eventually may pull development activities with it, because the physical presence of the $R \& D$ engineers can be required close to the production. [Sass, Szalavetz, 2014] 


\subsubsection{Samsung history and identity}

Large "chaebols" are characteristic of the Korean economy, which consolidated their dominant position thanks to generous subsidies in the "Park Chung Hee Era" starting from 1961. The highly centralized decision-making combined with the Confucian heritage of the Korean society gives a strong home country identity to the internationalizing Korean firm. "The enterprise culture attaches great importance to a "friendly relation to the environment," also when considering FDI. [Glowik, M. 2010:112]. At the same time as literature and empirical-based research underlines that "Korea's business elite has a preference for Western ways of thinking, which encouraged learning from industrialized countries along with imitation of advanced technology and management." [Glowik, M. 2010:114]. The network building attitude of Samsung emerged already at the birth of Samsung Electronics in 1969. The start of this "infant" industry in the Korean economy was strongly supported by Japanese technology and know-how transfer. By the Millenium Samsung Electronics (SE) had become Samsung Group's strongest division. SE with stable and prospective business performance in 1999-2007 overtook its Japanese competitors' global position, above all that of Sony. It concentrated on its core competence and related business segments including mobile phones. At the same time, Samsung internalized within its network with deep vertical integration the entire scope of the value chain from $R \& D$ till worldwide distribution and sales. Samsung Electronic's capability for the deep vertical integration derives from its "chaebol" character, where the "green-field" industrialization forced the large conglomerates to create within their networks all supportive functions including trading house and banking arm. The top management of Samsung recognized the danger of favouritism, buying from within the groups hindering competition and started to run each business unit as a separate profit centre, which supports competition with outside suppliers. [Glowik, M. 2010:125].

\subsubsection{Internationalization in the second half of the ' $80 \mathrm{~s}$ and entering the $\mathrm{V} 4$ region}

An important pillar of South Korean economic development has been the internationationalization of its companies. Samsung Electronics was the first Korean company which established in 1982 a manufacturing facility overseas, in Portugal, exactly in the field of colour TV set manufacturing, shortly before Portugal entered into the European Community. An acceleration of the global expansion started when Lee Kun-Hee took over the Samsung Group in 1987 after 5 decades from his father, who founded the company in 1938.

UK manufacturing was initiated in 1987, and shortly thereafter, in the very early stage of its internationalization, Samsung Electronics (SE) grabbed a sudden 
opportunity investment in a Hungarian TV factory of a major Hungarian manufacturer Orion in 1989 in the small town of Jászfényszaru, at $60 \mathrm{~km}$ distance from Budapest. Hungary was the first country from among the V4 countries, that has established diplomatic relations and parallelly signed major agreements on investment protection, avoidance of double taxation and the intergovernmental agreement on Scientific and Technological Cooperation with the Republic of Korea in 1989. Hungary's first inclusion into the global value chain of international corporations can also be explained by the factor of productivity difference among the four low-cost countries. Czech labour productivity on PPP exchange rates reached only $58 \%$, Polish one $39 \%$ and Slovakian one $18 \%$ of the Hungarian level in the mid-nineties. [Radosevic 2002:41]. „The gaps were swiftly narrowed and closed later on, which were reflected in the FDI results of the other V4 countries as well.” [Magasházi, Szijártó, Tétényi, 2015:15).

The Korean-Hungarian 50-50 \% joint venture of SE started its operation in April 1990, and by June $1990100 \%$ ownership was acquired by SE in the factory with an annual production of merely 200.000 pieces of television sets. A major jump in the production figures occurred in 1998 when the production was transferred from SE's British factory. By installing in 1999 the third production line, the factory became Europe's main manufacturing site, with a major contribution to the exceptionally high growth rate of output and exports in the Hungarian electronics industry in the second half of the nineties.

The global success of SE in the nineties, the positive experience with Samsung Electronics Hungary (SEH) paved the way for further expansion in the region. The investment decision in 2001 about a new factory in Galanta, Slovakia has brought an extraordinary expansion in the Slovakian electronics industry. The favourable experience in cost-competitiveness resulted in further consolidation of Samsung's TV production in Europe moving the production from the Barcelona factory and the remaining UK factory to Slovakia in 2002. Unemployment in Galanta reached 19 percent in 2002 and fell to 15 percent after the entry of Samsung employing 1000 persons. ${ }^{1}$ In 2006 a logistic and distribution centre was built in Galanta, in 2008 a new investment went to Voderady by the Samsung Display Division for LCD panel production - employing altogether 6000 people in Slovakia in the peak year, dominating the Slovakian electronics industry.

Although Samsung Electronics has not invested in a manufacturing plant in the Czech Republic, its sales company Samsung Electronics Czech and Slovak in Prague has an extensive sales and business development team with 145 employees. 


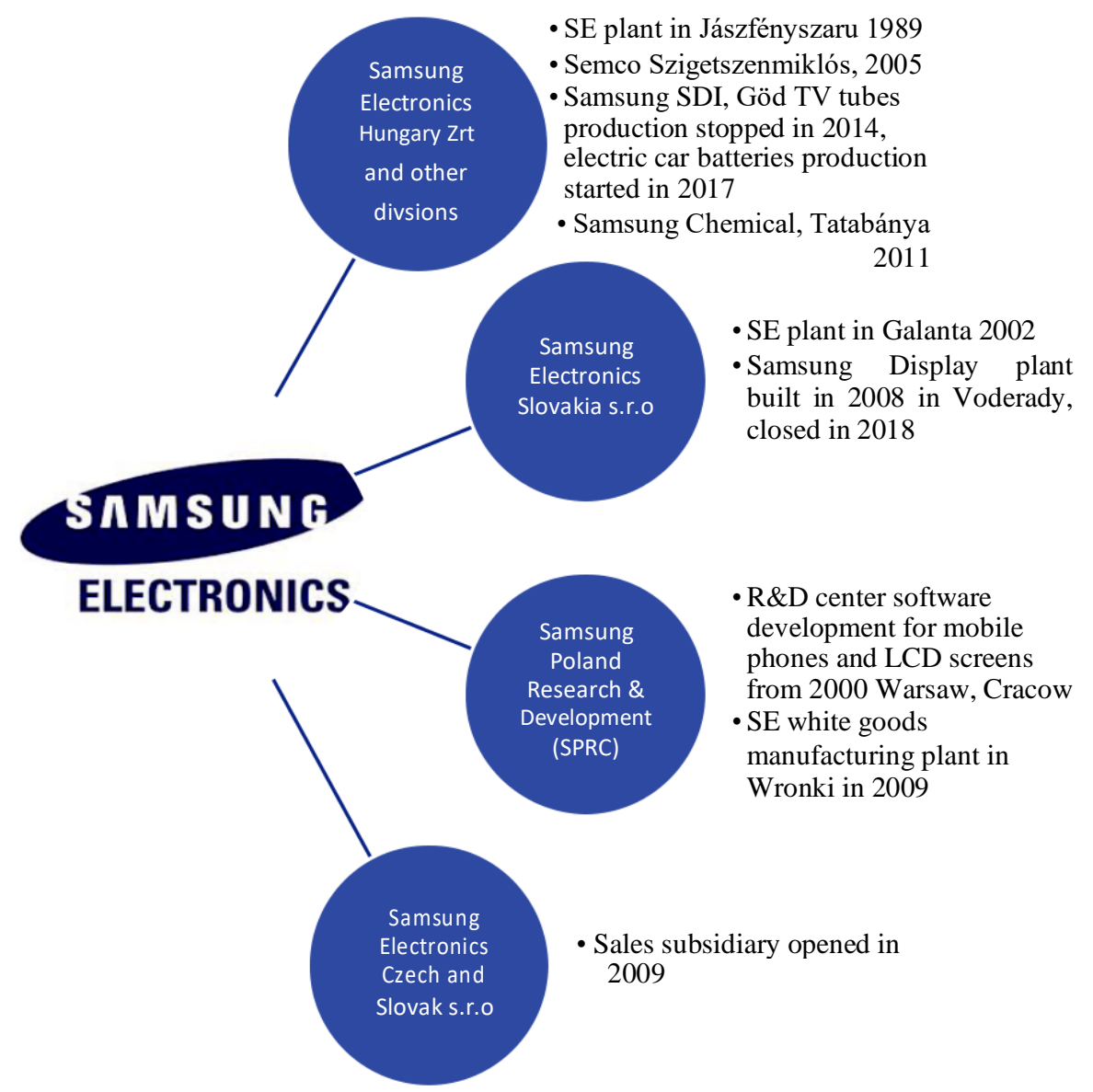

Source: Updated as of May 2021 based on Endrődi-Kovács, V., Kutasi, G., Magasházi , A. CEBR. Vol.7. No. 01. 2018 Figure 1. p. 20.

Chart 2. Samsung Electronics and other Samsung division's investments in the V4 region

Although SE does not have a TV manufacturing plant in Poland, Poland plays a special role in the global value chain of Samsung Electronics, especially in the ICT business line. In order to capitalize on local knowledge, in 2000 the Samsung Poland Research and Development Institute (SPRDI) was opened in Warsaw under the direct supervision of SE Korea. The institute developed at a very fast pace and claims to be the biggest and fastest-growing modern technology R\&D Centers in East-Central Europe. The high level of technical education, the conducive 
business environment behind the successful operation of the Institute and financial incentives contributed to the decision to open branches in other Polish cities in 2011-2013 in cooperation with local universities. In 2021, the Institute is operating at two sites, in Warsaw and Cracow and boasts of having submitted 200 patent applications, yearly 60 papers to scientific journals in its core areas of research, Artificial Intelligence and software development. The institute's researchers have high mobility within Samsung's international R\&D network. [SPRDI website].

\subsubsection{Level of upgrading within Samsung Electronics Global Value Chain}

The early and successful reaction of Samsung to technological change globally in the visual display industry has brought very fast product upgrading after the Millineum in the Hungarian, and in the Slovakian subsidiary, too. At the end of 1999 SEH started to produce digital TVs, in 2004 flat-panel LCD TVs, and in September 2005 as the first factory in Europe produced TVs with slim picture tubes, moving then later further to LED, OLED TV production. Although the products represented always the highest technological level, the main production activity has been assembling until today. Investment in new buildings allowed process upgrading, too. In a new plant from 2007 mainboards have been produced and chips surface mounted into the mainboards as a new, higher value-added production activity, increasing production value by $20 \%$ immediately at similar employment level. Process management systems, such as Kaizen have been adopted globally and locally to increase efficiency. The newest factory unit was opened in June 2014, enabling the production of extra-large TVs. Higher value-added functions such as sales, marketing, procurement, compliance, product programming, production process management were added to the assembly activity leading to functional upgrading and are concentrated on the site of the plant. [Magasházi, Szijártó, Tétényi 2015]. International expansion of SEH, managed out of Hungary, can be considered as a special functional upgrading element. The SEH branch opened near Oradea, in Madaras, Romania has been integrated as a lower cost base for job work production. Classical basic or applied R\&D functions, new products or application development have neither been transferred to Hungary nor to Slovakia, engineers employed (ca. $3 \%$ of the 3000 persons employed in Hungary) have been mainly managing the production process. 30 years later a substantial part of the blue-collar workers are still engaged in lower-skilled assembly activity, several hundreds of them in 2019 in both plants were coming from Serbia, Romania and Ukraine. A determined shift towards higher value-added, higher-paid activities has not occurred, plants have remained vulnerable to intra-company cost-optimizing efforts of SE. 
The Polish experience within SE's global value chain is different, supported also by an innovative restructuring of their educational system from 2000, honoured by TNCs not only from East -Asia but from Europe and the US as well (Motorola, Microsoft, Google, ABB, Unilever etc), which locate and expand their R\&D posts in the electronics industry to Poland.

4.2.4. National and local network connections, intra- and interfirm relationships analysed by the Global Production Network framework

Research points at the role of network elements as the main pulling factor apart from the EU demand for the inclusion of CEE countries in GPNs. The relationship between the global head office and local subsidiary plays a strong network alignment role, but a connection to national governments by both head office and subsidiary, relationship to local government by the subsidiary has its special significance [Radosevic S. 2002:55]. Tax allowances, grants in compliance with EU rules from the national government have had a positive contribution to SE's decision on new investments according to the interviews in Hungary and news reports from other V4 countries. Such allowances were mostly coupled both in Hungary and Slovakia with employment requirement commitments in return. In the case of the latest Hungarian investment in 2014 Samsung committed to employing 75 more FTE, while, SE Slovakia committed in 2012 to keep the number of its FTEs at the level of that time for 6 years in Voderady. It is not by chance, that the SE head office waited till 2018 to close down the Voderady plant. The V4 plants have remained still in the lower value-added segment, thus a competitive threat within the SE global value chain for new products and investments have been further increasing from China and Vietnam, where besides lower production costs, the substantial market increase is experienced by the rapidly increasing middle-class.

Local governments generally in the CEE region have an equally important role as national governments. After several years of lobbying towards the national government and 25 years of presence, road No. 32 connecting SEH with the highway was finally upgraded in Hungary. The dynamic mayor lady of Jászfényszaru, Dr. Marta Czegledi played personally a crucial role in safeguarding a conducive environment from the first day in 1989 till to this date in 2019. She and her colleagues in the other V4 countries act as trouble-shooters in the administrative jungle of rules and regulations of the transition economies. As the chaebol type of enterprise, culture aims at a friendly relation to the environment and if it meets with a dynamic proactive, cooperative local government, favourable social upgrading can be observed. The Hungarian host city, Jászfényszaru of merely 6000 inhabitants has kept its population level in the past 3 decades. The local government established 1998 its wholly-owned industrial park to support Samsung's further expansion and attract suppliers to its immediate proximity. 
Similar initiatives unfolded in Galanta as well. Traditional fields of arguments regarding the level of local taxes were handled in regular consultations with SE local management. Interviews conducted by the author in 2018 in Jászfényszaru revealed the decisive role of local educational institutions mainly at the secondary level to counteract increasing labour shortages, which induced SE to CSR contributions to this field. The Samsung Smart School was opened in 2014 in a historic building of Jászfényszaru and advanced IT education on the elementary level was supported by 30 smart classrooms.

Regarding intra-firm relations within the SE GPN head office - subsidiary relations of strategic issues, investments, mid-term planning are handled from the global head office, governance of the local production and sales in Hungary and Slovakia is run by joint Korean and domestic local management. Both in Hungary and Slovakia Korean language degrees were introduced in two major universities after 2007, at Comenius University in Bratislava and ELTE University in Budapest to contribute also to intercultural communication. With the continuous improvement of the production process and local skills, a technologically balanced, competitive situation emerged between the two large European production sites of Samsung. The Hungarian and the Slovakian units have supplied Samsung with the whole European market offering similar cost-level and investment benefits for the expansion. Shifting parts of production occurred due to currency appreciation before Slovakia joined the eurozone. SE Slovakia's revenues in Galanta fell in EUR terms and the subsidiary reported a net loss of 31 million EUR in 2007, while it achieved in 2006 still net profits of 106 million EUR ${ }^{2}$. SE's immediate response was to move the production of plasma TVs to Hungary at the beginning of 2009, motivated beside the push factor by the pull factor of weakening HUF. Lack of available workforce offered for lower value-added activity at the wage level ensuring the expected profitability led to the consolidation of the production activities within Slovakia, the Voderady plant was closed in 2018, 10 years of its inception and available nonforeign workers were motivated to move to the Galanta plant. ${ }^{3}$ Further reduction of employment in the remaining plant in Galanta came at the end of 2019, with the argument of changing global markets of television sets. Behind the reduction of workforce from 1500 to 1000 in 2020, a cost-optimization move could be observed again, two divisions were transferred to Hungary, where besides the advantage of the generous corporate tax cut from 2017, lower labour and energy costs measured in EUR terms can be booked in SE's consolidated balance sheet through the weak

\footnotetext{
2 Based on the study of Electrical Engineering in Slovakia in 2008. A project for the Ministry of Economy of Slovakia, September 2009.

3 https://spectator.sme.sk/c/20748727/samsung-will-shut-down-its-slovak-plant.html
} 
HUF. By the end of 2019 production volume halved and the number of employed decreased from 6000 in the peak period to altogether 1000 persons in SE Slovakia, which remains a major producer and exporter in the electronics industry.

Regarding interfirm relationships within the host countries, Radosevic concluded in 2002 that FDI driven development of the CEE electronics industry indicated only modest linkages with local SME supplier base at the end of the nineties [Radosevic 2002]. The research undertaken in 2015-2017 has shown, that the last decade strengthened local SMEs role in the network alliance architecture of SE. Samsung's globalization strategy aims to utilize local know-how and experience to be competitive and successful in the local markets. A few Korean suppliers came earlier in the nineties, which later on moved out again. The Korean Sangjin Micro built in 2014 its new factory in the Jászfényszaru Industrial Park for metal spare parts supply. SEH uses as a powerful lobbying argument towards the national government the 70-80 \% local supplier share, selected by strict procurement procedures. According to the interviews, SEH engineers invest heavily time and money into on the spot training of their suppliers, tacit knowledge is gained through several years of working together on thoroughly

negotiated economic, technical and quality assurance terms. The relational aspect with culture -to culture learning is such an asset, that has allowed a few major local SMEs of the region to grow together with their major client for several years. They are capable and are flexible to react immediately even in case of last-minute orders, confirmed also in two main supplier's interviews.

Two exemplary cases were analysed, based on desk stop research and interviews with SEH's representative and major local suppliers, Jász-Plasztik Ltd., Jászberény, start- ups in plastic moulding in 1990 and Ferro-Press, Jászberény in metal spare parts processing in Jászberény in 2002.

Jászplasztik applied for government grants and realized larger investments from the second half of the nineties, delivering to the two competitors in TV manufacturing, Samsung in Hungary and Sony in Slovakia. Jaszplasztik moved first with a joint venture to Galanta, Slovakia in 2001 to avoid border crossing restrictions in delivering Sony. Samsung Electronic's location search in 2002 led also to Galanta, becoming the neighbour of its Hungarian supplier. Jászplasztik employed 2200 persons in Slovakia, 3000 in Hungary and 450 in MadrasRomania, at the time of the author's interview with the owner in 2017, relying already on foreign labour, too both in Hungary and Slovakia. In 2011 SEH invited both suppliers to locate with them to Madaras, Romania. The two major Hungarian SEH suppliers represent positive cases to study the mechanism of how TNCs use nonequity mode suppliers (NEMs) for governance in their GPN in a relational context. The long term TNC-supplier relationship in Hungary, Slovakia and Romania has created the tacit knowledge behind the transaction of collaborating 
efficiently together, creating a kind of mutual dependence between the TNC and its supplier with increasing potential switching cost for the TNC. On the other hand, SEH as a client constitutes one-third of Jászplasztik's product portfolio and a break in the relationship would certainly impact severely the company. The giant modern production facilities, the embeddedness into the environment with the supplier and institutional linkages, constantly improving infrastructure in Jászfényszaru and Galanta during the 2-3 decades still safeguard the two locations.

Changes in SE's global position in the TV set product group, considerable geographical shifts in global market demand and disruptive changes in technology can however bring sudden challenges.

\section{THE COMPETITION AND COOPERATION OF EAST ASIAN FIRMS IMPACTING THE V4 REGION}

A major change in the television market was the replacement of the cathode ray technology of the 20th century with LCD and plasma TVs from 2005 onwards, which was dominated by the Asian manufacturers. A wide range of corporate websites, industry sectoral newsletters, academic journals was reviewed to give a concise picture in Enclosure 1. of the expanding activity of East Asian TV set and LCD panel groups in the 1989-2019 period in the V4 region. European manufacturers established international joint ventures with East-Asian counterparts to stay on the market. Philips transferred its display related business in a joint venture with LG, Thomson integrated its TV set business with TCL China from 2007 - but finally both exited TV set manufacturing, leading to the closure of their factory in the V4 (Philips in Hungary) or leaving over the business line to its cooperation partner - competitor. (TCL, TV Technology from Hong Kong). The majority of investments from 2007 in the European television set industry have been concentrated in Poland (LG Philips LCD, LG Electronics, Sharp, Toshiba, and Jabil). Industry clusters were expanding in Hungary around Samsung, the Czech Republic around Matsushita/Panasonic and IPS Alpha Technology, in Slovakia around Samsung and Sony. Samsung seems to have won the battle for the time being holding a $20 \%$ global market share, which benefits the development of its V4 subsidiaries. The Korean giants: Samsung and LG took over the market from their European and Japanese counterparts, which could not be hindered by alliances (Sony-Sharp, LG - Philips, Matsushita-Toshiba, Thomson-TCL), or involving EMS partners (Hon Hai).

Regarding the LCD panel segment, by 200820 LCD panel suppliers were located in Japan, South Korea, China and Taiwan. [Glowik, M. 2010:109]. The EastAsian economic literature has created a colourful metaphor, "water lilies" describing the diffusion of knowledge between the East-Asian LCD clusters 
stretching over the above countries. It illustrates through this sector, how the industrial cluster can become a regional competitive advantage through the efficiency-optimizing activity of TNCs. The configuration, how FDI flows creating clusters at distant new locations, resulting in knowledge dispersion to the new concentrated location - starting from Japan and arriving into Korea than moving further to China has resembled floating water lilies. „The ,water” between the lilies represents less developed, areas, unaffected by the positive impact of TNCs' investments". [Magasházi, 2021:66]. By 2012, Korean (LG Panel, Samsung), Japanese firms (Sharp) and Taiwanese enterprises ensured $90 \%$ of the global LCD panel demand. [Han, Oh. Yoo, 2012]. In 2020 Samsung Display still had a dominant market share, followed by other East-Asian players. In Europe, LCD panel manufacturing started in 2007 exclusively through FDI of East-Asian-based firms: three in Poland: LG Panel and Humax from Korea, and the Japanese Panasonic, Sharp in Czechia and Samsung in Slovakia. The cluster that emerged in the V4 countries has spread "water lilies" into the region. These firms compete with each other on capacity, prices, product development, process technologies, customers, marketing and capitalizations leading to reposition of the players, but they also cooperate in various fields. In 2012 Panasonic closed its factory in Poland, and in 2018 Samsung closed its LCD panel factory in Voderady, at that time employing 570 direct workers and 1000 externally hired ones (mostly Serbs). ${ }^{4}$

\section{CONCLUSION}

Whether FDI contributes to the economic and social goals of the host countries including sustainable development and social well-being is far not automatic. It depends on several external and internal factors. From the beginning of the 1990s, FDI has been the major vehicle of integration of electronics firms - foreign subsidiaries, EMS partners and local SMEs - based in the V4 countries into global production networks. By the end of the nineties, all four countries established themselves as low-cost electronics supply platforms. (HU - Samsung Electronics, Philips, SK- Sony, CZ - Matsushita, PL-LG, Thomson, Philips). With strong impact by Samsung Electronics (SE) FDI, the Hungarian productivity, manufacturing output and exports expanded in 1996-99 exceptionally well. In the first half of the nineties SE was seen globally as a producer of cheap television, but successfully modified this image with strong marketing efforts, innovative product design, large product development and $\mathrm{R} \& \mathrm{D}$ investments towards a premium brand manufacturer, offering a full TV product range. SE with a narrowly knitted vertical integration framework still produces most of the components of its final product by group affiliated companies. In 2020 the 
Samsung brand was $5^{\text {th }}$ on the world ranking, with $31,9 \%$ market share 2020 , has led the global television market for 15 consecutive years ${ }^{5}$. It has had a very strong impact on the Hungarian and Slovakian electronics industries. The year 2004 did not only bring the four Visegrad countries' entering the EU but a major disruptive technological change in TV manufacturing as well. The cathode ray tube (CRT) technology of the 20th century, mastered by Western-European manufacturers was suddenly replaced by LCD technology, where Asian producers had taken the lead in innovation and product development. The huge majority of the LCD-TV producers manufactured their products in-house, building up vertically organized GPNs, for which the V4 countries, above all Poland and Czechia, became hotspots with emerging clusters. The search identified more than 22 East-Asian manufacturers, and additionally an increasing Asian network of contract manufacturers and suppliers in the specialized areas in the V4 region. Japanese positions in the meantime have been taken over by the Korean global market leaders Samsung and LG, while the European players (e.g. Thomson, Philips) were replaced by the rapidly developing Chinese (including Hong Kong and Taiwan) firms entering through M\&A the V4 area (TCL). Although V4 countries played a supportive role in network alignment, through intensive local government support and industrial park support schemes, the move towards higher value-added, knowledge-based activitivities to be assigned by the East-Asian lead firm to their subsidiaries remains to be seen in the electronics manufacturing of all the four countries. The more active role of the national governments to develop the national innovation system and sectorally focused, high-quality educational programs could contribute to leaving the image of the low-cost electronics manufacturing base. The current position of V4 countries' firms within the global production networks has anyhow been challenged in recent years by the dramatically increasing labour shortage.

The two giant V4 plants' position within SE's Global Production Network with an escape route to second-tier production location for the lowest cost activities in Romania were deeper analyzed. The research results suggest that network alignment have been developed on all three levels: state-firm, intrafirm and interfirm during the 30 years of operation and seems to have created relatively strong embeddedness and longer-term commitment to the location. Product and functional upgrading trajectories could be identified, however, the major part of the production activity remained assembly work. The two large factories in neighbouring countries supplying the European market seem to strengthen each

5 https://www.flatpanelshd.com/news.php?subaction=showfull\&id=1614155663 Samsung tops global markets for 15 consecutive years 21.2 .2021 
other's position and their embeddedness in the V4 region despite their day to day competition. Although strict control follows the different locations from the Samsung Electronics head office, it is no the tax advantage that keeps SE in the region. The global minimum corporate income tax of $15 \%$, as endorsed in June 2021 by the G7 Finance Ministers is expected to have no major impact, even if it will be implemented by the G20, which grouping the Republic of Korea also belongs to. The most relevant factors are jointly production-related cost sensitivity and market proximity for the assembly segment of TV sets.

Looking at the global picture just before the onset of the global pandemics, Samsung Electronics consolidated its TV set production into a few worldwide locations ${ }^{6}$ and except for Hungary, all countries apply corporate income taxes (CIT) above $15 \%$.

\begin{tabular}{|l|l|l|l|l|}
\hline \multicolumn{6}{|c|}{ CIT in countries where Samsung TVs are assembled as of November 2019} \\
\hline Country & $\begin{array}{l}\text { Annual Capacity } \\
(p c s)\end{array}$ & No of employees & Major markets & \multicolumn{2}{c|}{ CIT'21 } \\
\hline Brazil & 10 million & & Latin America & $34 \%$ \\
\hline Egypt & 6 million & & Middle-East and Africa & $22,5 \%$ \\
\hline Hungary & 8 million & 3000 & Europe & $9 \%$ \\
\hline Mexico & 18 million & & US, Canada & $30 \%$ \\
\hline Romania & n.a. & & $\begin{array}{l}\text { Europe (through SEH } \\
\text { Hungary) }\end{array}$ & $16 \%$ \\
\hline Russia & $7-8$ million & & Russia, Eastern Europe & $20 \%$ \\
\hline Slovakia & monitors and TVs & 1500 & Europe & $21 \%$ \\
\hline Vietnam & n.a. & 60000 & Asia, Africa & $20 \%$ \\
\hline Korea & only pilot products & & no mass production anymore & $25 \%$ \\
\hline
\end{tabular}

Sources: government sites, PWC and Asia Briefing on CIT

Table 1. shows clear patterns for the importance of market access. The assembly plants in Jászfényszaru Hungary, and currently to a smaller extent in Galanta, Slovakia are the sole providers of TVs to the European Markets, except for Russia and some other Eastern - European countries that are supplied the Russian plant. Romania's support for production was more relevant in 2012-2015 during a strong market boom. The plant in Mexico supplies North America, Brazil in South America, in Egypt Middle East and Africa, while in Vietnam covers Asia and to a large extent Africa, too.

The importance of cost level is justified by Samsung's exiting from the Malaysian, Thai, Korean, Chinese and Indian TV set manufacturing operations in 2018-2019. The rising labour costs played a major factor behind shifting 
production to Vietnam in most of the cases, except for India, where a 5\% import duty levied on flat TV panels by the government motivated the decision to leave in 2019. The Indian government finally fine-tuned the relevant legislation mid-2020, and Samsung will resume operation in Chennai after 2 years production break. R\&D Centers remained in Korea, China-Shenzen and India, Bangalore.

The Samsung Group's strong commitment towards Vietnam as the location is reflected by the stock of FDI growing 26-fold between 2008-2018 to 17 billion USD, out of which 9,5 billion was invested by Samsung Electronics in its smartphone and television manufacturing complexes. ${ }^{7}$

The construction of a giant Samsung R\&D Complex started in spring 2020 in Hanoi. It is expected to be operational by the end of 2022 with a total investment of 220 million USD and will employ 3000 researchers.

There is an urgent need in the V4 countries to step forward towards knowledgebased activities soon in the field of electronics, as the closure of the Voderady plant in Slovakia in 2018 also confirms. Out of the four countries, Poland started to leap forward with a systemic education reform, accounting for the first results and attracted SE's R\&D and product development activity to Polish locations from 2000. Samsung has been the global market leader in television-set manufacturing for more than a decade, thus sudden exit due to market conditions has not endangered the V4 manufacturing units. The 30 years of Samsung Electronics in Hungary and 20 years in Slovakia certainly contributed to the development of of the local regions where they are situated in, has created employment also in a production-related engineering function, has taught local SME suppliers to adapt to global market circumstances. Relying on the current, mainly assembly type activities, however, cannot guarantee a future for these jobs in less than a decade. The 30 years of mass production knowhow, large facilities, disseminating risks geographically justify the V4 twin factory's position in the mid-term if labour shortage is handled and Samsung's innovation can keep its unparalleled market position, but the local municipalities and their national governments need to be equipped for the future.

7 ttps://vietnamnet.vn/en/sci-tech-environment/samsung-builds-us-220-million-r-d-centre-in-vietnam621055.html 


\section{REFERENCES}

\section{Books}

Coe, N. - Yeung, H. W. (2015): Global Production Networks: Theorizing Economic Development in an Interconnected World, Oxford, Oxford University Press ISBN-13: 978-0198703914

Glowik, M. (2010): Market Entry Strategies: Internationalization Theories, Network Concepts and Cases of Asian firms: LG Electronics, Panasonic, Samsung, Sharp, Sony and TCL China. Oldenburg Verlag, München

Magasházi A. (2021): Singapore Globally Entangled - Lessons for Central Europe? Epilogue on Covid-19 Impacts. Institute of Advanced Studies, Köszeg, 2021 Porter, M.E. (1985): Competitive Advantage. Creating and Sustaining Superior Performance. The Free Press, 1985. ISBN-13: 978-0684841465

Yeung H-W (2016): Strategic Coupling: East Asian Industrial Transformation in the New Global Economy. Ithaca. The US. Cornell University Press. ISBN 9781-5017-0255-6

\section{Book chapters}

Nikolaidis, K (1997): „East-European Trade” In: Robert O. Keohane, Joseph Nye, Stanley Hoffmann (ed): After the Cold War, International Insitutions and State Strategies in Europe. 1989-1991 Harvard University Press. Cambridge. Massachusets and London, England 1993. third printing 1997. ISBN 0-67400864-2 (pbk)

Magasházi A, Szijártó N, Tétényi A (2015): „Integrated in global value chains by Korean-V4 participation" In: Gress M, Grancay M (ed.) Mutual relations between the Republic of Korea and V4 countries in trade and investment. Conference proceedings International Scientific Conference and Workshop. 191 p. Bratislava: Vydavatelstvo Ekonóm, 2015. pp. 156-177. ISBN:978-80-2254207-4

\section{Journal articles}

Endrődi-Kovács, V., Kutasi, G., \& Magasházi, A. (2018): „Visegrád Group Expertise and Position in the Samsung Global Value Chain: A Case Study of Samsung Electronics in the V4 Countries." Central European Business Review, Prague 7 (1), 14-36. DOI: 10.18267/j.cebr.193

Gereffi G. Fernandez-Stark K, (2011): „Global Value Chain Analysis: A Primer”. Center of Globalization, Governance \& Competitiveness (CGGC) Duke University, Durham. North Caroline, USA.

Gereffy G. - Lee J: (2016) „Economic and Social Upgrading in Global Value Chains and Industrial Clusters: Why Governance Matters." Journal of Business Ethics, 
133 (1):25-38 Published Online first: 23 September 2014. 25-38 DOI 10.1007/s10551-014-2373-7

Henderson J. - Dicken P. - Hess M. - Coe N. - Yeung H.W. (2002): „Global Production Networks and the analysis of economic development." Review of International Political Economy 9. 436-464 o.

Humphrey and Schmitz (2002): "How Does Insertion in Global Value Chains Affect Upgrading in Industrial Clusters?" Regional Studies, Vol. 36. 9.: 10171027, 2002 DOI: 10.1080/0034340022000022198

Parrilli M.D., Nadvi K. \& Yeung H. W-C. (2013): „Local and Regional Development in Global Value Chains, Production Networks and Innovation Networks: A Comparative Review and the Challenges for Future Research," European Planning Studies, Vol.21. Issue 7. July 2013: 967-988. ISSN 1469-5944 (Online)

Pavlinek, P, Zizalova, P. (2014): "Linkages and spill overs in global production networks: firm-level analysis of the Czech automotive industry". Journal of Economic Geography 16 (2), 331-63

Radosevic S. (2002): „The electronics industry in Central and Eastern Europe: An emerging production location in the alignment of networks perspective". Working paper 21. Center for the Study of Economic and Social Change in Europe. School of Slavonic and East European Studies. University College London. March 2002. 1-64 ISSN 1476-1734

Sass, M. - Szalavetz, A. (2014): „Crisis-Related Changes in the Specialization of Advanced Economies in Global Value Chains". Competition \& Change. 18/2014 18: 54-69. ISSN 1024-5294

\section{Web pages:}

https://ec.europa.eu/eurostat/statistics-

explained/index.php?title=Archive:Electrical machinery and optical equip ment production statistics _NACE_Rev._1.1\&oldid=76969\#Further_Eurostat_information

Han, T. - Oh, K. - Yoo, I. (2012) From Bamboo Capitalism to Water Lily: LCD Industry in East Asian Countries. International Conference on Innovation and Information Management (ICIIM 2012). http://www.ipcsit.com/vol36/048ICIIM2012-M0133.pdf IPCSIT vol. 36 (2012) C (2012) IACSIT Press, Singapore http://www.ksh.hu/docs/hun/xstadat/xstadat_hosszu/h_qpt001.html https://www.industryweek.com/workforce/panasonic-close-czech-lcd-panelplant Source: Agence France Presse, 31st October, 2012 Radosevic S. (2004) The Electronics Industry in Central and Eastern Europe: A New Global Production Location. 1-16. https://www.researchgate.net/publication/27578648 


\begin{tabular}{|c|c|c|c|c|c|c|c|c|}
\hline \multicolumn{2}{|c|}{ Enlosure 1.} & \multicolumn{7}{|c|}{ Investments of the largest East-Asian TV manufacturers in the V4 region (1989-2019) } \\
\hline Company name & home cy & $\begin{array}{l}\text { rank } \\
2018\end{array}$ & host cy & $\begin{array}{l}\text { 1st } \\
\text { invest. }\end{array}$ & $\begin{array}{c}\text { Invested (initial) } \\
\text { amount }\end{array}$ & Expansion & Location & Remarks \\
\hline Samsung Electronics & Korea & 1. & $\mathrm{HU}$ & $1989 / 90$ & $530(20) \mathrm{mUSD}$ & $2007 / 2014$ & Jászfényszaru & $2003 \mathrm{SK}, 2009, \mathrm{RO}$ managed by $\mathrm{HU}$ \\
\hline Samsung SDI & Korea & & $\mathrm{HU}$ & 2002 & n.a. & 2007 & Göd & Closed in 2014, 2016 new car battery inv. \\
\hline Samsung Electro $\mathrm{M}$. & Korea & & $\mathrm{HU}$ & 2001 & $20 \mathrm{mUSD}$ & TV comp. & Szigetszentmiklós & Supplies components for display assembly \\
\hline Samsung Electronics & Korea & & SK & 2003 & $750 \mathrm{mSVK}+70 \mathrm{mEUR}$ & $2006 / 2012$ & Galanta & Voderady workers offered job in Galanta \\
\hline Samsung Display & Korea & & SK & 2008 & n.a. & LCD Pane & Voderady & Voderady closed in 2018 , labour shortage \\
\hline Samsung Electronics & Korea & $(R \& D)$ & $\mathrm{PL}$ & 2000 & n.a. & $2011 / 13$ & Warsaw & Poznan, Lodz till 2015, Cracow remained \\
\hline Daewo Electronics & Korea & & $\mathrm{PL}$ & 1994 & & TVs & Pruszkov & closed in 2009 \\
\hline LG Philips/LG & Korea & 2. & $\mathrm{PL}$ & 1999 & $64 \mathrm{~m}$ USD & LCD TV & Mlawa & \\
\hline LG Philips/LG & Korea & 2. & $\mathrm{PL}$ & 2007 & $560 \mathrm{~m}$ USD & 2012 OLED & near Wroclaw & LG cluster - European hub of subsidiaries \\
\hline Humax & Korea & & $\mathrm{PL}$ & 2006 & 30 mio EUR & LCD panel & Belchatow & \\
\hline Sony/Foxconn & Japan & 5. & SK & 1996 & 124 mio USD & 2008 LCD & Trnava, then Nitra & in 2010 Foxconn bought $90 \%$ of Sony Nitra \\
\hline Hisense & China & 4. & $\mathrm{HU}$ & 2004 & n.a. & LCD-TV & Sárvár,Szombathely & Closed down in 2009 \\
\hline Matsusita/Panasonic & Japan & 10. & $\mathrm{CZ}$ & $1997 / 2006$ & 4,3 billion $\mathrm{CZK}$ & LCD-TV & Plzen & el. resistor and relay plants came in 1999 \\
\hline Panasonic/IPS Alpha & Japan & & $\mathrm{CZ}$ & 2007 & n.a. & LCD pane & Zatec & Closed down in 2012 \\
\hline Changhong & China & 2. $\mathrm{CHN}$ & $\mathrm{CZ}$ & 2006 & 30 mio EUR & LCD TV & Nymburg & \\
\hline Funai Electric & Japan & & $\mathrm{CZ}$ & 2007 & n.a. & LCD-TV & Nowa Sol & in 2010 name changed to Funai Europe \\
\hline Sharp & Japan & & $\mathrm{PL}$ & 2007 & 44 mio. EUR & LCD pan & Lysomice/Torun & supplies to Sharp, Spain \\
\hline Toshiba/Vestel & Japan/TK & & $\mathrm{PL}$ & 2007 & $43 \mathrm{~m}$ USD & LCD TV & Wroclaw & in 2016 Turkish Vestel acquires the plant \\
\hline Hon Hai (Foxconn) & Taiwan & EMS & SK & $2005 / 2010$ & 80 mio USD/n.a. & & Nitra,Pardubice & Sony factory sold to Hon Hai \\
\hline $\mathrm{TCL}$ & China & 3. & $\mathrm{PL}$ & 2018 & AI R\&D Center & & Warsaw & \\
\hline Thomson, TCL & FR/China & 3. & $\mathrm{PL}$ & $1997 / 2004$ & 301 mio USD & $2013 / 2018$ & Zyrardow & JV TTE 2004-2007 failed, TCL brand \\
\hline TPV Technology & $\mathrm{NL} / \mathrm{HK}$ & 7. & $\mathrm{PL}$ & 2008 & n.a. & & Gorzow & \\
\hline TP Vision/Philips & $\mathrm{NL} / \mathrm{HK}$ & & $\mathrm{HU}$ & $1990 / 2012$ & (25) m USD & & Székesfehérvár & 2013 production transferred to $\mathrm{PL}$ \\
\hline TP Vision/Philips & $\mathrm{NL} / \mathrm{HK}$ & & $\overline{P L}$ & $1995 / 2012$ & $101,2 \mathrm{~m} \mathrm{EUR}$ & 2007 & Kwidzyn & Plant taken over by EMS Jabil Circuit \\
\hline
\end{tabular}


